\title{
Keragaan Sumber Kitin untuk Mempertahankan Virulensi Beauveria bassiana (Bals.), Jamur Pengendali Wereng Batang Cokelat (Nilaparvata lugens Stal.)
}

\author{
Performance of Chitin Sources to Enhance Beauveria Bassiana (Bals.) Virulence \\ as Rice Brown Planthopper Fungal Control
}

\author{
Nova Laili Wisuda ${ }^{1) *} \&$ Subur Sedjati ${ }^{1}$ \\ 1)Program Studi Agroteknologi, Fakultas Pertanian Universitas Muria Kudus \\ Kampus Gondangmanis PO. BOX 53 Bae, Kudus, Jawa Tengah 59352 \\ *Penulis untuk korespondensi.E-mail:nova.laili@umk.ac.id
}

Diterima 19 September 2017; diterima untuk diterbitkan 30 Juli 2018

\begin{abstract}
Beauvaria bassiana is an entomopathogenic insect that effectively controls brown planthopper (BPH), but will decrease it virulences if nutrients containing chitin and protein is not added. The aim of this research is to find the best method of $\mathrm{B}$. bassiana propagation with the addition of shrimp and cricket flour, both are chitin sources. Isolates were cultured with Potato Dextrose Agar (PDA) medium and continued with rice medium. This research method used non-factorial Completely Randomized Design (CRD) with three treatments consisting of control, addition of shrimp flour and addition of cricket flour per treatment each with six replications. The research parameters consist of percentage of mortality, percentage of conidia rising time and LT50 test. The chitin sources could increases the growth rate from $0.69 \mathrm{~cm}$ per day to $1.449 \mathrm{~cm}$ per day and increases the spore density by $4.8 \times 10^{6} \mathrm{CFU}$ (colony forming unit) up to $8.2 \times 10^{6} \mathrm{CFU}$. Chitin also affects the virulence of $\mathrm{B}$. bassiana in BPH where it can increase the percentage of death starting from $3 \%$ until $10 \%$ and made lethal-time of BPH faster from 0.25 to 0.45 day. There is no significant difference between the sources of chitin between shrimp and cricket flour, so it is more advisable to use cricket flour because it is less expensive.
\end{abstract}

Keywords: biological control, entomo-pathogen, fungi, insects, pest

\section{INTISARI}

Beauvaria bassiana merupakan serangga entomopatogen yang efektif mengendalikan wereng batang cokelat (WBC), namun akan mengalami penurunan virulensi bila tidak diberikan nutrisi yang mengandung khitin dan protein. Penelitian ini bertujuan menemukan metode terbaik perbanyakan B. bassiana yang dilakukan dengan penambahan tepung ebi dan penambahan tepung jangkrik yang merupakan sumber kitin. Isolat dibiakkan dengan medium perbanyakan Potato Dextrose Agar (PDA) dan diteruskan hingga perbanyakan beras. Metode penelitian ini menggunakan Rancangan Acak Lengkap (RAL) non-faktorial dengan 4 perlakuan dan 6 ulangan yang terdiri atas kontrol, tanpa tambahan kitin, penambahan tepung ebi dan penambahan tepung jangkrik. Parameter penelitian terdiri atas persentase mortalitas, persentase waktu munculnya konidia dan uji LT50. Pemberian sumber kitin meningkatkan kecepatan pertumbuhan hingga $0,69-1,49 \mathrm{~cm}$ per hari dan meningkatkan kerapatan spora berkisar 4,8 $\times 10^{6}-8,2 \times 10^{6} \mathrm{CFU}$ (colony forming unit). Kitin juga berpengaruh terhadap virulensi B. bassiana pada WBC dimana mampu meningkatkan persentase kematian 3-10\% dan waktu paruh kematian WBC 0,25-0,45 hari lebih cepat. Tidak ada perbedaan yang berarti antara sumber khitin dari tepung jangkrik dan tepung ebi sehingga lebih disarankan untuk menggunakan tepung jangkrik karena lebih murah dan mudah didapat.

Kata kunci: agensia hayati, entomopatogen, hama, jamur, serangga

\section{PENDAHULUAN}

Di Indonesia pada umumnya, pengendalian hama masih banyak menggunakan insektisida kimia yang dilakukan secara intensif, yang dapat mengakibatkan berbagai dampak negatif, terutama terbunuhnya musuh alami dan akumulasi residu racun. Wereng batang cokelat (WBC) merupakan salah satu hama utama padi yang berkemampuan reproduksi cukup tinggi, dengan potensi telur per betina diperkirakan 486 butir dan siklus hidup kurang lebih 25 hari pada varietas IR 64 (Habibi et al., 2016). Pengendalian WBC oleh petani selalu dilakukan menggunakan insektisida kimia dan seiring dengan penggunaannya terjadi pertambahan dosis serta frekuensi yang memengaruhi terjadinya 
resistensi dan resurjensi. Hasil penelitian Ratna et al. (2010) menunjukkan, aplikasi insektisida pada WBC mengakibatkan peningkatan jumlah keturunan berikutnya sekitar 222 nimfa dibandingkan tanpa insektisida yang jumlah keturunan hanya sekitar 181 nimfa. Sementara itu pada aplikasi deltametrin dengan konsentrasi yang sama $(50 \mathrm{ppm})$ diperoleh hasil yang berbeda, yakni pada frekuensi 1 kali dengan jumlah keturunan 110 nimfa, sedangkan pada frekuensi 2 kali memiliki jumlah keturunan 235 nimfa.

Beauveria bassiana (Bals.) merupakan jamur entomopatogen yaitu jamur yang dapat menimbulkan penyakit pada serangga sehingga sering digunakan sebagai agensia biologi dalam bentuk ragi untuk pengendali beberapa serangga hama (Samson et al., 1988), jamur ini memiliki kemampuan menyebabkan kematian 78,14\% pada ulat kubis dengan LT50 2,67 hari (Suharto, 2004). Jamur entomopatogen cukup efektif diaplikasikan pada berbagai jenis wereng karena kemudahan produksi massal, penyimpanan, virulensi, dan aplikasi serta selektif hanya pada hama sasaran (Toledo et al., 2010).

Virulensi adalah indikator penting untuk mengukur potensi efikasi jamur terhadap hama dan biasanya dilakukan bioassay skala laboratorium. Jamur entomopatogen aktif melakukan penetrasi melalui kutikula serangga dan melepaskan enzim kutikula, menghidrolisis secara ekstraseluler dalam dekomposisi protein, kitin, dan lipid, yang merupakan komponen utama dari kutikula (Samson et al., 1988). Penambahan kitin bisa menjadi penentu dari virulensi dari B. bassiana, dalam hal ini biasa ditambahkan dengan ekstrak kitin pekat yang di Indonesia cukup sulit didapatkan dan mahal. Alternatif lain dapat digunakan pengganti dengan ekstrak dari Artropoda seperti udang, jangkrik, dan belalang. Pada penelitian Herlinda et al. (2012) media Glucose Yeast Agar (GYA) ditambahkan dengan tepung jangkrik dengan hama sasaran kutu pepaya. Pada penelitian ini dibandingkan keefektifan antara tepung ebi dan tepung jangkrik pada media Potato Dextrose Agar (PDA) karena hal ini dapat berpengaruh terhadap metode yang tepat untuk preparasi $B$. bassiana sebagai bio-insektisida khususnya pada pengendalian WBC.

\section{BAHAN DAN METODE}

\section{Rancangan Penelitian}

Penelitian dilakukan pada bulan Juni-Oktober 2016 di laboratorium Agronomi dan laboratorium
Proteksi, Fakultas Pertanian Universitas Muria Kudus (UMK) pada ketinggian $17 \mathrm{mdpl}$. Penelitian ini menggunakan Rancangan Acak Lengkap (RAL) satu faktor dengan empat perlakuan:

a. Kontrol atau tanpa perlakuan Beauveria bassiana

b. Tanpa tambahan sumber kitin pada media (PDA dan perbanyakan beras)

c. Penambahan tepung ebi pada media ( $2 \%$ pada PDA dan perbanyakan beras)

d. Penambahan tepung jangkrik pada media ( $2 \%$ pada PDA dan perbanyakan beras)

Masing-masing perlakuan diulang sebanyak 6 kali, data hasil pengamatan dianalisis sidik ragam dan apabila terjadi beda nyata akan dilakukan uji lanjut dengan LSD 5\% menggunakan Microsoft Excel 2016.

\section{Perbanyakan Wereng Batang Cokelat}

Wereng batang cokelat yang digunakan dibiakkan di Fakultas Pertanian Universitas Muria Kudus sejak 2015 dipelihara di dalam stoples (dia-meter $30 \mathrm{~cm}$ ) yang didalamnya telah berisi padi yang berumur 1 minggu untuk pakan dan tempat ber-kembangbiak. Setelah bertelur dan menetas, nimfa selanjutnya dipindah ke tempat yang baru dan meng-hasilkan F2 dan seterusnya.

\section{Pembuatan Suspensi Beauveria bassiana}

Pembuatan suspensi jamur B. bassiana diawali dengan memperbanyak medium beras. Beras disterilkan selama 5 menit di dalam autoclave kemudian dilakukan penanaman di dalam laminar air flow (LAF) yang sebelumnya telah disterilkan dengan sinar ultra violet selama 15 menit. Kultur murni jamur B. bassiana yang telah disiapkan sebelumnya dimasukkan ke dalam medium beras yang disediakan dengan menggunakan jarum ose. Biakan ditutup rapat dan disimpan di dalam tempat yang aman; ditunggu selama 21 hari sebelum siap digunakan. Larutan suspensi $B$. bassiana dibuat dengan mengambil dan menimbang $17 \mathrm{~g}$ beras yang sudah disiapkan sebelumnya, kemudian dihaluskan dan dimasukkan ke dalam botol serta ditambah $100 \mathrm{ml}$ air suling steril; selanjutnya digojok menggunakan shaker merek Optima tipe OS-762 selama 24 jam untuk siap diaplikasikan dengan kecepatan 300 osilasi/menit. Kerapatan spora yang didapatkan dalam suspensi $100 \mathrm{ml} \mathrm{B.} \mathrm{bassiana}$ adalah $6 \times 10^{7}$ spora/ml, suspensi ini yang digunakan untuk perlakuan semprot. 


\section{Uji Patogenitas}

Pengujian dimulai dengan mempersiapkan bibit padi yang telah berusia 2 minggu selanjutnya bibit diberi suspensi jamur sesuai perlakuan. Bibit direndam menggunakan larutan suspensi $B$. bassiana selama 10 menit dan kemudian diangkat dan dikeringanginkan selama 10 detik. Bibit yang sudah direndam diletakkan di dalam stoples yang telah modifikasi dengan penyangga akar dan air untuk ruang hidup tanaman. Serangga uji berupa WBC kemudian dimasukkan ke dalam stoples yang telah berisi bibit padi; selanjutnya dilakukan pengamatan sampai 10 hari setelah larutan suspensi diberikan.

\section{Laju Pertumbuhan Miselium Beauveria bassiana}

Kecepatan pertumbuhan miselium (v) didapatkan menggunakan rumus menurut Lilly \& Barnet (1951) cit. Handiyanto et al. (2013):

$$
V=\frac{(\text { Diameter koloni akhir }- \text { Diameter koloni awal) }}{\text { Rentang jumlah hari }}
$$

\section{Kerapatan Spora}

Spora dihitung menggunakan alat hemocytometer dengan metode penentuan kerapatan spora sebanyak $1 \mathrm{ml}$. Hemocytometer yang telah ditetesi suspensi $B$. bassiana dihitung kerapatan sporanya menggunakan hand-counter di bawah mikroskop binokuler dengan perbesaran 400 kali. Kerapatan spora dihitung dengan menggunakan rumus Gabriel \& Riyatno (1989) cit. Herlinda et al. (2006).

$$
C=\frac{t}{n \times 0,25} \times 10^{6}
$$

Keterangan:

$$
\begin{aligned}
\mathrm{C} & = \\
\mathrm{t} & \text { kerapatan spora per } \mathrm{ml} \text { larutan } \\
& \text { jumlah total spora dalam kotak sampel } \\
& \text { yang diamati } \\
\mathrm{N} & =\text { jumlah kotak sampel }(5 \text { kotak besar } \times 16 \\
& \text { kotak kecil) } \\
0,25 \quad= & \text { faktor koreksi penggunaan kotak sampel } \\
& \text { skala kecil pada hemocytometer }
\end{aligned}
$$

\section{Mortalitas dan LT50}

Persentase mortalitas WBC dilakukan dengan cara menghitung jumlah WBC yang telah mati, dengan menggunakan rumus Prijono (1989) cit. Herlinda et al., 2006):

$$
P=\frac{a}{a+b} \times 100 \%
$$

Keterangan:

$\mathrm{P}=$ Persentase mortalitas

$\mathrm{a}=$ Jumlah WBC yang mati

$\mathrm{b}=$ Jumlah WBC seluruhnya (yang hidup dan mati)

$\mathrm{LT}_{50}$ diperoleh dari regresi linier dengan persamaan

$: y=a x+b$ dimana " $y$ " untuk mortalitas , " $x$ " untuk waktu kematian.

\section{HASIL DAN PEMBAHASAN}

\section{Laju Pertumbuhan Miselium Beauveria bassiana}

Laju pertumbuhan miselium $B$. bassiana menunjukkan bahwa penambahan kitin berpengaruh pada kecepatan pertambahan panjangnya. Perbedaan signifikan terlihat pada jangkrik dan non kitin, namun demikian tidak ada perbedaan nyata antara non kitin dan ebi maupun dibandingkan dengan jangkrik. Laju pertumbuhan secara nyata didominasi oleh penambahan sumber kitin dari jangkrik dimana memperoleh kelajuan $1,88 \mathrm{~cm}$ per hari dan hasil terendah yaitu pada non kitin dengan kelajuan $0,39 \mathrm{~cm}$ per hari. Kemampuan pertumbuhan yang lebih cepat karena tambahan tepung jangkrik disebabkan karena tepung ini banyak mengandung protein dan kadar kitinnya tinggi. Protein merupakan nutrisi yang digunakan jamur untuk perbanyakan sel, pembentukan miselium dan spora, sedangkan kitin merangsang serangga untuk membentuk enzim kitinase yang bersifat sebagai pemecah kutikula. Menurut Ummidi dan Vadlamani (2014), kutikula serangga mengandung fibril kitin dalam matriks protein membentuk ikatan dengan lipid, lilin, jumlah kecil dari fenol dan pigmen yang merupakan ikatan kompleks, yang dalam hal ini kitinase berperan aktif untuk memecahnya (Gambar 1).

Afandhi et al. (2012) menyatakan bahwa biakan B. bassiana asal isolat Spodoptera litura memiliki laju pertumbuhan yang lebih cepat yaitu 2,2 mm per hari dibandingkan asal isolat tanah yang berkisar $0,83 \mathrm{~mm} /$ hari, diperkuat Li et al. (2014) jamur Beauveria brongniarti asal isolat Anomala corpulenta memiliki aktivitas kitinase $18,7 \mathrm{U} / \mathrm{ml}$, paling tinggi dibanding Beauveria isolat lain. Aktivitas kitinase juga berbanding lurus dengan laju pertumbuhan koloni dengan $B$. brongniarti asal isolat $A$. corpulenta memiliki hasil tertinggi yaitu pada umur 15 hari mampu mencapai 3,7 mm per hari (Li et al., 2014). Laju pertumbuhan sangat berkaitan erat dengan nutrisi fungi yang harus terpenuhi dengan menambahkan 


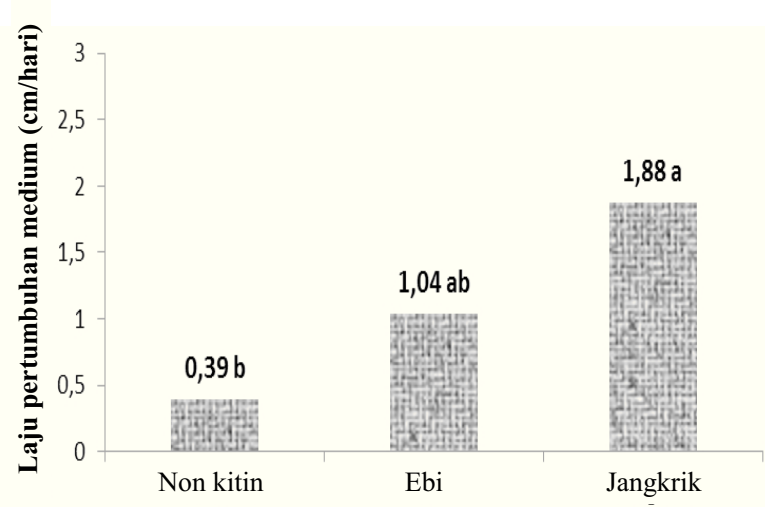

Beauveria bassiana pada media PDA dengan tambahan

Angka yang diikuti huruf yang sama tidak berbeda nyata pada uji LSD taraf $5 \%$

Gambar 1. Laju Pertumbuhan miselium isolat murni Beauveria bassiana dibiakkan pada media Potato Dextrose Agar (PDA)

sumber kitin, dalam hal ini tambahan tepung ebi dan jangkrik mampu meningkatkan laju pertumbuhan (Gambar 1).

\section{Kerapatan Spora Beauveria bassiana}

Perhitungan spora menunjukkan terjadinya peningkatan jumlah pada perlakuan penambahan sumber kitin, hasil tertinggi diperoleh sumber kitin dari ebi yaitu $5,52 \times 10^{7}$ colony forming unit (CFU) dan hasil terendah pada non kitin dengan jumlah $4,70 \times 10^{7}$ CFU. Dari semua perlakuan tidak terjadi perbedaan nyata pada analisa ANOVA dan uji lanjut LSD taraf $5 \%$. Kerapatan spora tertinggi pada perlakuan dengan penambahan kitin dengan menambahkan tepung ebi dan disusul perlakuan tambahan tepung jangkrik. Tidak ada beda nyata pada perlakuan nonkitin, namun hal ini mengindikasikan bahwa tambahan kitin memberikan nutrisi yang lebih baik pada biakan B. bassiana. Senada dengan penelitian Li et al. (2014) kerapatan spora yang tertinggi yaitu $1,39 \times 10^{8} \mathrm{CFU}$ pada biakan entomo-patogen $B$. brongniarti dengan aktivitas enzim kitinase tertinggi yang diperoleh dari substrat kitin kumbang Anomala. Afandhi et al. (2012) menyatakan bahwa biakan B. bassiana asal isolat $S$. litura yang merupakan serangga hama memiliki koloni dengan berbentuk cekung. Bentuk ini adalah indikasi dari isolat yang virulen, berbeda dengan isolat asal tanah yang memiliki bentuk cembung yang mengindikasikan sifat tidak virulen. Nuryanti et al. (2012) melaporkan rata-rata jumlah spora $B$. bassiana berkisar antara $2,38 \times 10^{8} \mathrm{CFU}$ sampai dengan $2,61 \times 10^{8} \mathrm{CFU}$ dengan hasil terbaik pada tepung belalang. Beauveria bassiana akan lebih

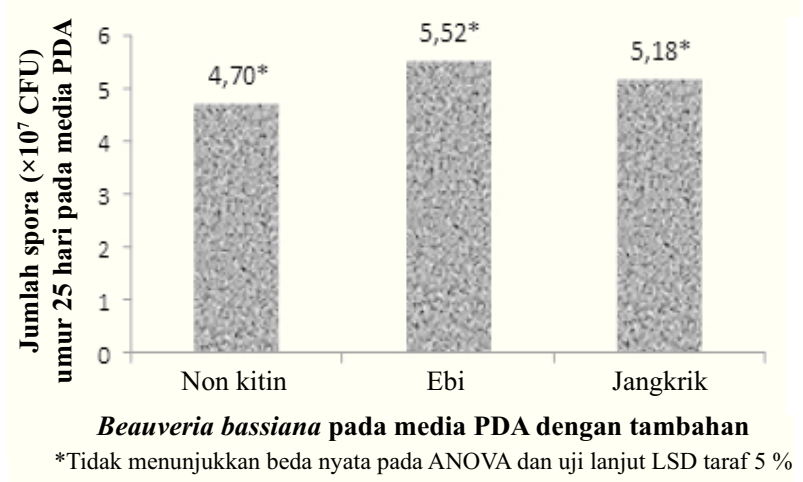

Gambar 2. Kerapatan spora Beauveria bassiana dibiakkan pada media beras umur 25 hari

virulen bila mendapatkan nutrisi kaya akan kitin, baik itu diperoleh secara alami maupun buatan (Gambar 2).

\section{Mortalitas Wereng Batang Cokelat}

Mortalitas pada hari ke-3 menunjukkan bahwa pemberian kitin menyebabkan peningkatan kematian yang signifikan dibanding tanpa tambahan, hasil tertinggi pada tepung jangkrik (38\%) dengan tidak berbeda nyata dengan tepung ebi $(32 \%)$. Kedua tambahan sumber kitin ini berbeda nyata dengan hasil pada suspensi jamur yang tidak diberi tambahan kitin dengan mortalitas sebesar 19\%. Kontrol memperoleh hasil yang terendah $(3,4 \%)$ dan berbeda nyata dengan semua perlakuan dengan aplikasi $B$. bassiana. Hari ke-4 perlakuan $B$. bassiana tambahan tepung ebi memiliki mortalitas tertinggi (72\%) dan tidak berbeda nyata dengan sumber kitin dari tepung jangkrik (66\%), namun terjadi beda nyata dibandingkan dengan aplikasi $B$. bassiana tanpa tambahan kitin (59\%). Hari ke-5 perlakuan B. bassiana dengan tambahan ebi masih menunjukkan hasil tertinggi kematian WBC (91\%) dan masih tidak berbeda nyata dengan tambahan tepung jangkrik $(85 \%)$, serta memiliki pola yang sama dengan hari sebelumnya yaitu berbeda nyata dengan perlakuan B. bassiana tanpa tambahan kitin (82\%). Kontrol pada hari ke-4 dan ke-5 berbeda nyata dengan semua perlakuan lain dengan kematian WBC kurang dari 5\% (Tabel 1).

Efek ramuan $B$. bassiana pada WBC mengakibatkan kehilangan nafsu makan pada 2 hari pertama, yang dalam pengamatan gerakannya cenderung pasif dibandingkan kontrol. Kematian terjadi pada hari ke- 3, namun munculnya miselium terjadi pada satu hari setelah kematian (Gambar 3), dan karena 
Tabel 1. Mortalitas wereng batang cokelat (WBC) akibat perlakuan Beauveria bassiana

\begin{tabular}{lrcc}
\hline Perlakuan B. bassiana & \multicolumn{4}{c}{ Mortalitas (\%) pada hari ke- } \\
\cline { 2 - 4 } & \multicolumn{1}{c}{3} & 4 & 5 \\
\hline Kontrol & $3,4 \mathrm{c}$ & $4,4, \mathrm{c}$ & $4,8 \mathrm{c}$ \\
Tanpa sumber kitin & $19,0 \mathrm{~b}$ & $59,0 \mathrm{~b}$ & $82,0 \mathrm{~b}$ \\
Tambahan tepung jangkrik & $38,0 \mathrm{a}$ & $66,0 \mathrm{ab}$ & $85,0 \mathrm{ab}$ \\
Tambahan tepung ebi & $32,0 \mathrm{a}$ & $72,0 \mathrm{a}$ & $91,0 \mathrm{a}$ \\
\hline
\end{tabular}

Keterangan: Angka yang diikuti huruf yang sama pada kolom yang sama tidak berbeda nyata pada uji LSD taraf 5\%.

tubuh WBC cukup kecil serta cairan tubuh yang sedikit, perkecambahan miselium hanya bertahan sampai hari ke-3 setelah kematian. Aplikasi B. bassiana dengan tambahan khitin menunjukkan pengaruhnya terhadap tren kenaikan kematian pada hari ke-3. Semua perlakuan $B$. bassiana secara signifikan berbeda dengan kontrol. Mortalitas pada hari ke-3 menunjukkan pemberian kitin mampu meningkatkan kematian yang signifikan dibanding tanpa tambahan. Secara umum perlakuan B. bassiana dengan tambahan tepung ebi memberikan hasil kematian tertinggi WBC dan diikuti oleh perlakuan tambahan tepung jangkrik. Walaupun demikian, meski perlakuan $B$. bassiana dengan tambahan tepung ebi berbeda nyata dengan perlakuan tanpa kitin, pada perlakuan jangkrik terjadi kematian yang lebih tinggi namun tidak menunjukkan perbedaan signifikan dengan perlakuan tanpa kitin (Gambar 4).

Pemberian tambahan nutrisi mengandung kitin jelas berimplikasi terhadap kemampuan virulensi jamur entomopatogen, dalam hal ini adalah $B$. bassiana. Peneltian sebelumnya pemberian tepung jangkrik pada biakan Saborroud Dextrose Broth (SDB) dapat

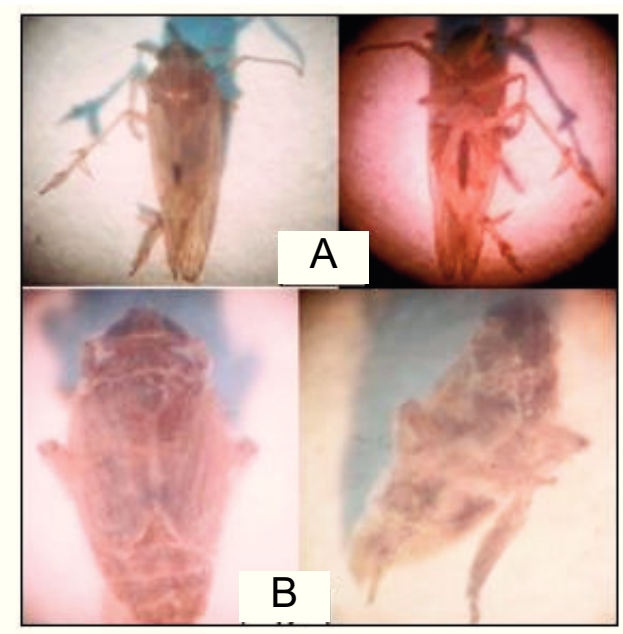

Gambar 3. Wereng batang cokelat (WBC) normal posisi dorsal dan ventral (A), WBC terinfeksi Beauveria bassiana posisi dorsal dan ventral (B)

menyebabkan mortalitas larva Plutella xylostella antara $69,47 \%$ dan $71,97 \%$, dimana berbeda signifikan dengan biakan tanpa tambahan kitin (Herlinda et al., 2006). Aplikasi B. bassiana dengan substrat jagung giling mampu menyebabkan kematian pada Wereng Punggung Putih (WPP) hingga 66,67\% ketika pada biakan tersebut diberi tambahan nutrisi berupa kitin yang berasal dari Ekstrak Kompos Kulit Udang (EKKU) sehingga dapat meningkatkan virulensi jamur B. bassiana (Herlinda et al., 2008). Penelitian selanjutnya oleh Herlinda (2012), masih menggunakan EKKU pada media biakan beras dengan bahan pembawa kompos yang mengandung jamur Trichoderma virens, ternyata mampu membunuh $82,86 \%$ nimfa pada kutu putih Paracoccus marginatus.

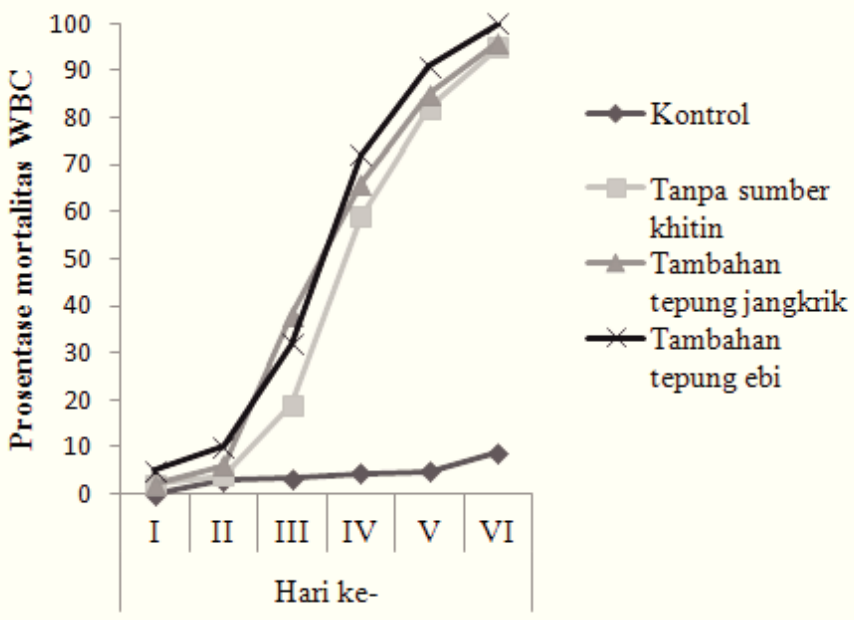

Gambar 4. Tren kematian WBC akibat perlakuan Beauveria bassiana dari hari ke-1 sampai ke- 6 
Pada kasus lain penambahan sumber kitin pada media beras sebagai media perbanyakan $B$. bassiana juga berpengaruh pada mortalitas walang sangit. Penambahan tepung belalang secara nyata menyebabkan mortalitas tertinggi yaitu $78 \%$, disusul perlakuan penambahan tepung dedak dengan mortalitas walang sangit mencapai $71 \%$ dan penambahan tepung kulit udang hanya sekitar 54\% (Nuryanti et al., 2012). Sumber kitin dari Kelas Insecta akan memberikan pengaruh yang baik terhadap spora fungi entomopatogen, karena kitinnya memiliki karakteristik yang sesuai dengan inangnya, dalam penelitian ini antara tepung ebi dan tepung jangkrik tidak terjadi beda nyata namun terlihat jelas bahwa tambahan kitin mampu meningkatkan kemampuan virulensi B. bassiana terhadap WBC (Tabel 1). Tidak ada perbedaan yang berarti antara sumber kitin dari tepung jangkrik dan tepung ebi sehingga lebih disarankan untuk menggunakan tepung jangkrik karena lebih murah dan lebih mudah didapatkan.

\section{KESIMPULAN}

Penambahan sumber kitin pada media perbanyakan PDA maupun beras mampu meningkatkan laju pertumbuhan, kerapatan spora, dan virulensi Beauveria bassiana. Pemberian sumber kitin mampu meningkatkan laju pertumbuhan hingga 0,69-1,49 $\mathrm{cm}$ per hari dan meningkatkan kerapatan spora berkisar $4,8 \times 10^{6}-8,2 \times 10^{6} \mathrm{CFU}$, hal ini menunjukkan bahwa nutrisi yang terkandung pada tepung jangkrik dan tepung ebi berdampak terhadap pertumbuhan jamur entomopatogen $B$. bassiana. Kitin juga berpengaruh terhadap virulensi $B$. bassiana pada WBC dimana mampu meningkatkan persentase kematian 3-10\% dan waktu paruh kematian WBC $0,25-0,45$ hari lebih cepat. Studi tentang komposisi serta kombinasi tambahan perlu dilakukan untuk mendapatkan hasil biakan yang baik dan bervirulensi memadai.

\section{UCAPAN TERIMA KASIH}

Penelitian terlaksana atas dukungan dana dari Lembaga Penelitian Universitas Muria Kudus. Apresiasi juga penulis tujukan kepada Fakultas Pertanian atas dukungan fasilitas dan kemudahan akses selama penelitian berlangsung.

\section{DAFTAR PUSTAKA}

Afandhi, A., S.R.C. Syamsidi, S.M. Mimbar \& B. Wiroatmojo. 2012. Isolation and Phenotypic Characterization of Morphology in Fungus Beauveria bassiana (Balsamo) Vuillemin Colony Naturally from Leaf Surface, Soil, and Insect as Host in Tomato Plantation. A GRIVITA 34: 303 310.

Habibi, I., Witjaksono, \& A. Wijonarko. 2016. On the Migration Process of Brown Planthopper Fed Using Susceptible and Resistant Rice Varieties. Jurnal Perlindungan Tanaman Indonesia 20: $72-78$.

Handiyanto, S., U.S. Hastuti \& S. Prabaningtyas. 2013. Pengaruh Medium Air Cucian Beras terhadap Kecepatan Pertumbuhan Miselium Biakan Murni Jamur Tiram Putih, hlm. 1-6. Dalam S. Kubikazari, H. Rahmawati \& A. N. Khalifah (ed.), Seminar Nasional X Pendidikan Biologi 6 Juli 2013. UNS Press, Surakarta.

Herlinda, S., K.A. Darmawan, Firmansyah, T. Adam, C. Irsan, \& R. Thalib. 2012. Bioesai Bioinsektisida Beauveria bassiana dari Sumatera Selatan terhadap Kutu Putih Pepaya, Paracoccus marginatus Williams \& Granara De Willink (Hemiptera: Pseudococcidae). Jurnal Entomologi Indonesia 9: 81-87.

Herlinda, S., Hartono, \& C. Irsan. 2008. Efikasi Bioinsektisida Formulasi Cair Berbahan Aktif Beauveria bassiana (BALS.) VUILL. dan Metarhizium sp., hlm. 1-15. Dalam A. Hayati, A. Yanuarti, T.W. Widowati, H. Agustina, Hersyamsi, F. Pratama, A.N. Triana \& Puspitahati (ed.), Seminar Nasional dan Kongres PATPI 14-16 Oktober 2008. PATPI, Palembang.

Herlinda, S., M.D. Utama, \& Y. Pujiastuti. 2006. Kerapatan dan Viabilitas Spora Beauveria bassiana (BALS.) Akibat Subkultur dan Pengayaan Media, serta Virulensinya terhadap Larva Plutella xylostella (Linn.). Jurnal Hama dan Penyakit Tumbuhan Tropika 6: 70-78.

Nuryanti, N.S.P., L. Wibowo, \& A. Azis. 2012. Penambahan Beberapa Jenis Bahan Nutrisi pada Media Perbanyakan untuk Meningkatkan Virulensi Beauveria bassiana terhadap Hama Walang Sangit. Jurnal Hama dan Penyakit Tumbuhan Tropika 12: 64-70.

Ratna, Y., Y.A. Trisyono, Witjaksono, \& D. Indradewa. 2010. Pengaruh Konsentrasi dan Frekuensi Aplikasi Deltametrin terhadap Resurjensi Nilaparvata lugens. Jurnal Perlindungan Tanaman Indonesia 16: 6-14. 
Samson, R.A., H.C. Evans \& J.-P. Latge. 1988. Atlas of Entomopathogenic Fungi. SpringerVerlag, Berlin. 187 p.

Suharto. 2004. Patogenisitas Beberapa Isolat Beauveria bassiana pada Plutella xylostella. Jurnal Perlindungan Tanaman Indonesia 10: 8-12.

Toledo, A.V., A.M.D. Lenicov, \& C.C.L. Lastra. 2010. Histopathology Caused by the Entomopathogenic Fungi, Beauveria bassiana and
Metarhizium anisopliae, in the Adult Planthopper, Peregrinus maidis, a Maize Virus Vector. Journal of Insect Science 10: 1-10.

Ummidi, V.R.S. \& P. Vadlamani. 2014. Preparation and Use of Oil Formulations of Beauveria bassiana and Metarhizium anisopliae against Spodoptera litura Larvae. African Journal of Microbiology Research 8: 1638-1644. 